\title{
Letting my imagination run wild Archival sources as creative inspiration at Gustavus Adolphus College
}

D uring the January Interim Experience at Gustavus Adolphus College in Saint Peter, Minnesota, students and faculty are immersed in one subject for four weeks in courses that are innovative, experimental, and experiential. These courses provide a unique opportunity for students and faculty alike to explore nontraditional topics in imaginative ways. In 2011, librarians Julie Gilbert and Anna Hulseberg taught a new January term course, Fact and Fiction, in which students examined the intersection of the historical record and imagination through the experience of the reader, researcher, and writer. Our students read and discussed works

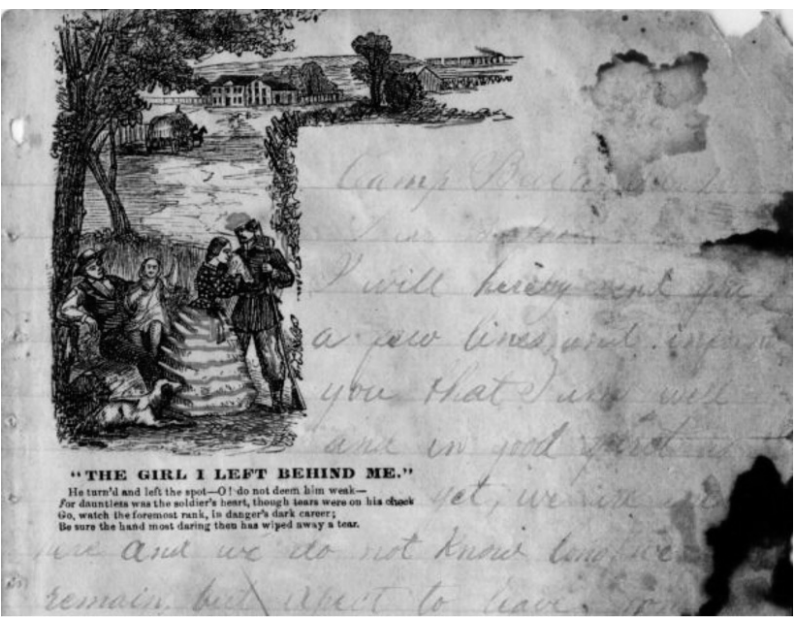

Letter from Olof Nelson to his brother written on February 20, 1864. Courtesy of the College and Lutheran Church Archives, Nelson, Olof. Civil War Letters of Olof Nelson and Family History Materials, 1864-1945. CAMC Collection 86. on the psychol-

ogy of reading, historical fiction, and a semi-autobiographical novel. The course culminated in the creation of an original work of fiction, inspired by primary sources in the College and Lutheran Church Archives that students selected with the help of archivist Jeff Jenson. The three of us found that the project far exceeded our expectations; not only did it expose students to a resource entirely new to them in the archives, it unlocked students' imaginations and fostered their creative voices, cultivating the idea that research —and writing - are profoundly creative.

\section{New life for old sources}

Hulseberg and Gilbert designed the project to give students a hands-on learning experience to explore the relationship between fact and fiction. We wanted them to grapple with the role that research can play in the creative process by requiring them to use a primary source as inspiration. Students also located secondary sources that would help them better understand the historical context of the primary source. By turning their research into fiction, students confronted some of the same issues that authors of historical fiction face, namely, the extent to

Julie K. Gilbert is librarian at Folke Bernadotte Memorial Library, e-mail: jgilber2@gustavus.edu, Anna Hulseberg is librarian at Folke Bernadotte Memorial Library, e-mail: ahulsebe@gustavus.edu, Jeff A. Jenson is college and Lutheran Church archivist, e-mail: jjenson@gustavus. edu, at Gustavus Adolphus College

(c) 2011 Julie K. Gilbert, Anna Hulseberg, and Jeff A. Jenson 
which an author can fictionalize an account or invent new aspects while remaining true to the source material.

The project also dovetailed with Jenson's goals for the archives and student learning. The College and Lutheran Church Archives at Gustavus exists to make available for use and study significant historical materials. As with most academic archival repositories, the archives fields many traditional research questions dealing with past students, faculty, and administrators, as well as questions about athletics, sororities, programs, and the ever popular topic-buildings. Yet in numerous encounters with student researchers, Jenson has never assisted with a creative writing assignment. By directing students to primary sources from the archives, the project reinforced the very mission of the archives: collected materials should be used rather than just preserved. Through the Fact and Fiction course, the three of us were uniquely positioned to witness students using these materials in ways that were new to all of us-students, instructors, and archivist alike.

\section{Orienting the researcher}

We knew that students succeed best at using archival materials when given a thorough introduction to the basics of using an archival repository. Since only two students in the class of 22 had ever used the archives before (and some did not even know of its existence), we used several methods to connect students with archival collections. After we introduced the project itself, students visited the archives during one class period for an orientation. While students had additional time during class to visit and begin consulting their primary source, we also required students to visit the archives at least once outside of class time.

In order to help students approach the materials available in the archives, Jenson and his assistant compiled a list of 40 sources pulled from various collections, avoiding typically dry institutional records in favor of collections that might be compelling to un- dergraduates. Materials documented various aspects of the college, as well as personal manuscripts, and papers dealing with the Lutheran Church in America. We aimed to make research less burdensome on both students and archives staff by promoting fully processed collections with finding aids located online and in the library's catalog.

The narrowing of possible topics provided focus, "spark[ed] inspiration," and made the process "easier than just coming up with a story out of the blue," according to a few participants. Students reviewed the list of selected collections, picked topics that appeared interesting, and then read the appropriate finding aids. Although this process worked well for most students, a few switched topics after visiting the archives, in part due to the lack of robust documentary textual evidence in their original collections.

Many participants were inspired by the research process itself. Although not required, several students returned to the archives on multiple occasions to continue studying their topics. Some students needed additional help based on the collection they used. For example, archives staff aided students having trouble deciphering 100year-old handwriting, while obtaining additional primary sources for others. Generally, however, the research process progressed smoothly. As one student related, "I really loved this experience ... . I would love to use archival sources again." Due in part to the efforts the three of us made to introduce students to the archives, Fact and Fiction students arrived ready to research with an understanding of how the process worked.

\section{Sources of inspiration}

Examples from two of the most popular archives collections used by students in the class illustrate the range of ways students used primary sources to inspire their creative works. Three students selected sources from the Civil War Letters of Olof Nelson, which contains correspondence from Swedish immigrant Nelson to his family written while he served in the Union Army's 55th Illinois 
Infantry during the American Civil War from 1864 to 1865.

One student conducted secondary research on Civil War-era weaponry and daily camp life; his story centered on the relationships between Union soldiers in a Civil War camp. Another student investigated soldier life before and after the war and set her story among a gathering of Civil War veterans. She incorporated flashbacks to the soldiers' encounters with a Southern family during the war and the compassion the soldiers felt for the Rebels as human beings, despite being on opposite sides of the conflict. Finally, a third student wrote a thriller about a Union special operations contingent that stopped

the assassination attempt on Abraham Lincoln and changed history.

A nother popular collection was the Tornado of 1998 Collection, which i n c l u d e s newspaper clipping , photographs, personal accounts, and

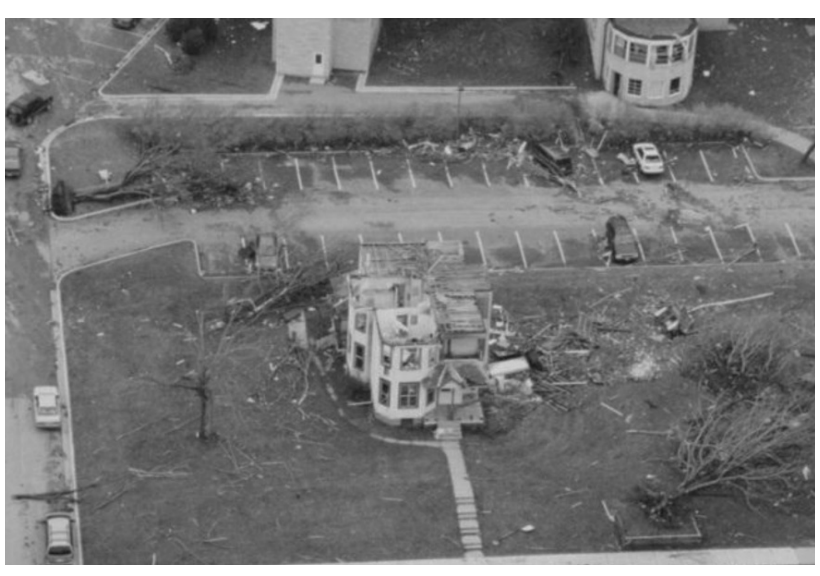

Destroyed Swedish House on the campus of Gustavus Adolphus College. Courtesy of the College and Lutheran Church Archives, Tornado of 1998 Collection, 1998 and Ongoing. CAMC Collection 24. other docu-

ments pertaining to the tornado that struck the city of St. Peter and Gustavus Adolphus College in March 1998.

Three students wrote stories related to the tornado and conducted additional research on topics such as the tornado as weather phenomenon, the effect of living through natural disasters on children, and public relations efforts by the college after the tornado. One student wrote a character study about an individual who had gone through the tornado as a young child and was telling a friend about it some years later. Another student wrote a story as a series of reflections from the perspectives of tornado survivors from various walks of life. Finally, a third student wrote about a group of friends who were first-year Gustavus students durgraduation day four years later. It was fascinating to see the variety of sources students selected, the range of secondary sources they consulted, and the different directions in which they took stories that were based on the same collections.

\section{Fostering creativity}

In addition to meeting the goal of creating an original work that embodies the question of fact and fiction, the creative writing ing the tornado; the story was set on their project existed simply as an opportunity for students to write creatively, which is something most do not do on a regular basis, unless they are enrolled in a creative writing course.

While the class naturally drew several students who pursued creative writing on their own, the majority of students in the course had not written creatively since junior high or high school, and even then their experiences were sporadic: "I have had no experience with creative writing in college, and very little in my latter years of high school. So this was all very new to me," wrote one student. For most students, the prospect of writing creative fiction was beyond their comfort zones. "I am not a fan of creative writing," one student stated.

By the end of the course, however, most students indicated their enjoyment of the 
writing process, due in large part to working with their primary source. "It's as though I was on a moving platform. A good foundation that would help move the story forward when I got a block," one student said.

Others found that the primary source significantly helped develop elements of the story: "As the author, I was able to portray more dynamic characters and experiences because I felt connected to a real event and time." One student became so tied to the primary source that writing about it became a very personal experience: "It felt close to home for me so I worked hard to make sure I did it justice at least."

\section{Encouraging lifelong research and writing}

We hope that the experience will foster long term practices of creative writing and ongoing use of archival collections. When we asked at the end of the course, almost half of our students said they plan to work on their stories in the future, while others were much more certain that they would revisit this story or even start a new one. "Maybe over the summer!" said one student.

Others said that they would not continue working on their stories, citing reasons such as lack of time or, as one student stated, "creative writing is not my thing." At the very least, students gained an appreciation of the writing process itself: "I now appreci- ate what writers do, and how hard their jobs actually are."

While most students do not anticipate using the archives again as undergraduates unless it is required in a class, most expressed positive experiences using the facility: "I think it's quite interesting," reported one student.

The assignment proved valuable as it encouraged students to conduct original research and gave them insight into an often underused resource. They learned the fundamentals of what archives hold, the difference between archives and libraries, and the basics of accessing, understanding, and using primary source materials. Furthermore, many gained an appreciation of the unique treasures contained in an archives: "[I]t was an experience you can't get from anything else .... to actually hold the documents in your hand is an unparallel[ed] experience."

For us, the project was successful on all levels. When we teach the class again, we will spend even more time searching for sources in the archives and talking about writing during class. We want to provide students with the time and space to unlock their creativity in both researching and writing. Our goal is for all students to have an experience similar to this one: "The project as a whole was an excellent idea-I've never done anything like it before. It really let my imagination run wild." $n$
("Lightening fast ..." continued from page 533)

One thing I would do differently, however, is instead of purchasing so many first generation Kindles, I would wait and purchase more of the second and third generations. Hard to believe, but the first generation, almost four years old, looks like ancient technology compared to the second and third generations.

For now, UNO will continue loaning Kindles, both for ILL and regular circulation, as long as our patrons continue to use them and as we evolve into the next transformation-whatever that may be.

\section{Notes}

1. UNO's use of the Kindle does not constitute an endorsement of this product.

2. Kit Eaton, "Amazon sells more e-books than paper ones," Fastcompany.com, http:// www.fastcompany.com/1754259/amazondeclares-the-e-book-era-has-arrived (accessed Sept. 15, 2011).

3. Kristen Purcell, Pew Internet, "E-reader ownership doubles in six months," http:// pewinternet.org/Reports/2011/E-readers-and -tablets/Report.aspx (accessed July 6, 2011). n 